\title{
Carbon dioxide emission in hydrogen production technology from coke oven gas with life cycle approach
}

\author{
Piotr Burmistrz ${ }^{1}$, Leszek Czepirski ${ }^{1}$ and Magdalena Gazda-Grzywacz ${ }^{1, a}$ \\ ${ }^{1}$ AGH University of Science and Technology, Faculty of Energy and Fuels, al. Adama Mickiewicza 30, 30-059 Cracow, Poland
}

\begin{abstract}
The analysis of Carbon Footprint (CF) for technology of hydrogen production from cleaned coke oven gas was performed. On the basis of real data and simulation calculations of the production process of hydrogen from coke gas, emission indicators of carbon dioxide (CF) were calculated. These indicators are associated with net production of electricity and thermal energy and direct emission of carbon dioxide throughout a whole product life cycle. Product life cycle includes: coal extraction and its transportation to a coking plant, the process of coking coal, purification and reforming of coke oven gas, carbon capture and storage. The values were related to $1 \mathrm{Mg}$ of coking blend and to $1 \mathrm{Mg}$ of the hydrogen produced. The calculation is based on the configuration of hydrogen production from coke oven gas for coking technology available on a commercial scale that uses a technology of coke dry quenching (CDQ). The calculations were made using ChemCAD v.6.0.2 simulator for a steady state of technological process. The analysis of carbon footprint was conducted in accordance with the Life Cycle Assessment (LCA).
\end{abstract}

\section{Introduction}

Coal is one of the most important primary energy sources and, in contrast to oil and natural gas, its resources are much larger and located in all geographical regions [1-2]. World coal resources, estimated by EURACOAL [3] account 726 mld tones, while according to WEC - 826 mld tones [4]. Coal is not only used as a fuel to generate heat and electricity, but also as a raw material in pyrolysis process, gasification and for direct hydrogenation of coal.

Nowadays, excluding electric power industry, the pyrolysis process is the most popular way of coal processing. The raw material is heated without the access of oxygen to about $1300 \mathrm{~K}$ and the main products are: coke, coke oven gas, tar, benzol and depending on the gas purification technology: ammonium sulfate, sulfur or sulfuric acid. Currently, about $80 \%$ of the global coke production is located in Asia, including nearly $70 \%$ in China. CRUs forecasts [5] confirm, that a similar proportions in the sector will sustain in the coming years. According to CRU - world coke production will rise and the estimated production in 2017 will reach about 793 million tones [5, 6-8]. Coking plants creates a threat to the environment [9-11]. It is worth noting that coking process gives the possibility of obtaining hydrogen from purified coke oven gas - which contains more than 50 vol. $\% \mathrm{H}_{2}[12,13]$.

Hydrogen is not present in large quantities and concentrations on Earth [14]. It is mainly obtained from biomass, water and fossil fuels due of their wide availability [15]. Interest in hydrogen as a fuel [16, 17] due to the fact that during reaction with oxygen a significant amount of energy is being released $143.1 \mathrm{MJ} / \mathrm{kg}$ and the only reaction product is water. Hydrogen being used in fuel cells allows direct conversion of chemical energy in the reaction with oxygen into electricity. It is also a base material of many chemical syntheses, in which many substances, both organic and inorganic may be produced [18]. Global hydrogen production comes mainly from fossil fuels processing without CCS (Carbon Capture and Storage) technologies: $48 \%$ from natural gas, $30 \%$ from the refinery off-gases, $18 \%$ from coal and the rest comes from electrolisys and biomass [19-24].

Environmental footprints are widely use to assess the impact of technology on the environment. Scientists have developed and implemented a lot of indicators showing the impact of human activities on the environment, for example: energy footprint [25], water footprint [26], nitrogen footprint [27] and carbon footprint [28]. Carbon footprint (CF) is the most objective method of assessing the technology impact on the environment in the aspect of the greenhouse effect $[29,30] . \mathrm{CF}$ is a measure of the total amount of Greenhouse Gas emission (GHG - greenhouse gas), both direct and indirect, throughout the life cycle of a product or technology. The methodology of analysis and calculation of the $\mathrm{CF}$ is based on Life Cycle Assessment (LCA), a research into potential aspects of environmental impact in the whole life cycle that is, on each of its stages - from obtaining raw materials,

\footnotetext{
${ }^{\text {a }}$ Corresponding author: magdago@agh.edu.pl
} 
through production, until the utilization and/or recycling of the main product [31-36].

The aim of this study was to analyze the CF of hydrogen production from purified coke oven gas. Calculations were made and an evaluation of indicators of direct and indirect $\mathrm{CO}_{2}$ emissions resulting from the cycle of obtaining hydrogen were performed, including the following steps: coal mining, transport of coal to coking plants, coking process and hydrogen production from purified gas, and operations of $\mathrm{CO}_{2}$ capture and sequestration. For this calculations methodology of LCA described in ISO 14040:2009 was used [37].

\section{General information, and assumptions}

An analysis of CF for the technology of hydrogen production from coke oven gas derived from coking of coal blend with the characteristics given in Table 1 was performed. CF of the hydrogen production was calculated in accordance with standard ISO 14067:2014 [38] and included both direct and indirect emissions associated with electricity and heat consumption during coal mining, coal transport from mine to coking plant, coal blend preparation, coking process, cooling and cleaning gas and its reforming.

Table 1. Characteristics of coal blend

\begin{tabular}{|l|r|r|}
\hline \multicolumn{1}{|c|}{ Mark } & \multicolumn{1}{c|}{$\begin{array}{c}\text { As } \\
\text { received }\end{array}$} & \multicolumn{1}{c|}{$\begin{array}{c}\text { Dry } \\
\text { basis }\end{array}$} \\
\hline $\mathrm{C}[\%]$ & 77.4 & 84.3 \\
\hline $\mathrm{H}[\%]$ & 4.2 & 4.6 \\
\hline $\mathrm{N}[\%]$ & 1.2 & 1.3 \\
\hline $\mathrm{S}_{\mathrm{t}}[\%]$ & 0.5 & 0.5 \\
\hline $\mathrm{O}[\%]$ & 2.4 & 2.6 \\
\hline $\mathrm{W}_{\mathrm{t}}[\%]$ & 8.2 & - \\
\hline $\mathrm{A}[\%]$ & 6.1 & 6.6 \\
\hline
\end{tabular}

\subsection{Coal mining processes}

Investigated coking coal blend (Tab. 1) is composed of several coking coals obtained from mines with high absolute methane content. Therefore, the assumption was made, that $60 \%$ of methane is captured and used to produce electricity and heat, while the rest present in the ventilation air (methane concentration below 2\%) is catalytically combusted. To estimate the values of $\mathrm{CO}_{2}$ emission in the production of coal was assumed that: to produce $1 \mathrm{Mg}$ of coal a mine consumes on average $68.02 \mathrm{kWh}$ of electric energy and 43.98 MJ of heat (by commercially available technology),

- the results of calculations show that in the case of the ventilation air containing $0,5 \%$ of methane, it is necessary to provide the $486 \mathrm{~kJ}$ heat on $1 \mathrm{~m}^{3} \mathrm{CH}_{4}$ for the catalyticall combustion process

- emission of $\mathrm{CO}_{2}$ from burning methane at the power plant is $1.9643 \mathrm{~kg} \mathrm{CO} / \mathrm{m}^{3}$ and $1.9951 \mathrm{~kg} \mathrm{CO} \mathrm{CO}_{2} / \mathrm{m}^{3}$ from catalytic combustion,
- the rate of electricity consumption to produce compressed air is $0.0833 \mathrm{kWh} / \mathrm{m}^{3}$,

- in Polish conditions production of $1 \mathrm{kWh}$ of electricity generates $\mathrm{CO}_{2}$ emission equal to $0.9124 \mathrm{~kg}$, while producing $1 \mathrm{GJ}$ of heat energy generates $63.4600 \mathrm{~kg} \mathrm{CO}_{2}$ emission.

Based on the above the calculated $\mathrm{CF}$ from the combustion of methane is $20.6027 \mathrm{~kg} \mathrm{CO}_{2}$ per $1 \mathrm{Mg}$ of mined coal, while the catalytic combustions generates $\mathrm{CF}$ value of $33.2449 \mathrm{~kg} \mathrm{CO} / \mathrm{Mg}_{\text {coal. }}$. As a result of methane combustion $28.4317 \mathrm{kWh}$ of electricity, $0.0701 \mathrm{GJ}$ of heat and $5.1 \mathrm{~m}^{3}$ of compressed air per $1 \mathrm{Mg}$ of coal is obtained. This allows to save $0.4248 \mathrm{kWh} / \mathrm{Mg}$. Thus, coal mining under the precise conditions present in the mine consumes net $39.1590 \mathrm{kWh} \mathrm{/} \mathrm{Mg}_{\text {coal }}$ electricity and $-0.0261 \mathrm{GJ} / \mathrm{Mg}$ heat. A negative value means, that the amount of heat produced by the power plant (at the mine) is greater than mine requires.

\subsection{Coal transporting to coking plant}

Based on the data obtained from the company transporting coal from the mine to the coking plant a rate of electricity consumption during by rail transportation $(0.0789 \mathrm{kWh} / \mathrm{Mg} \cdot \mathrm{km})$ was assumed. This generates indirect emission of carbon dioxide associated with the transport of raw materials $0.072 \mathrm{~kg} \mathrm{CO} / \mathrm{Mg} \cdot \mathrm{km}$ $(0.003 \mathrm{~kg} \mathrm{CO} /(\mathrm{GJ} \cdot \mathrm{km}))$. It was assumed that coking plant is located $100 \mathrm{~km}$ from the mine.

\subsection{Coking process}

The coking process is carried out in the chambers of the coke oven battery system with a volume of $30 \mathrm{~m}^{3}$ useful chamber. The battery is heated exclusively by own coke gas. After completion of the coking process, the basic product - coke at a temperature of $1000^{\circ} \mathrm{C}$, is pushed out of the chamber, cooled, sorted and transported to customers. Raw coke oven gas is purified by ammonia absorption in the scrubber, where the reduction of $\mathrm{H}_{2} \mathrm{~S}$ and $\mathrm{NH}_{3}$ to a level below $0.5 \mathrm{~g} / \mathrm{m}^{3}$ and $0.03 \mathrm{~g} / \mathrm{m}^{3}$ is obtained, respectively. The composition of raw coke oven gas is given in Table 2. The mixture of steam and gas from absorption system is moved to catalytic decomposition of $\mathrm{NH}_{3}$ and sulfur production by Claus process. In the next step, benzol is absorbed from purified gas by ammonia method. The purified gas is divided into two equal streams, one of them is used for own coking plant requirements and the other is used for the hydrogen production.

Energy supply for preparation and coking coal departments were estimated based on the information on technological solutions in coking plants available on a commercial scale, specifically these using technology of coke dry quenching. During coke dry quenching a large part of the physical enthalpy of the hot coke is recovered and it is used to produce steam and electricity for coking plants own consumption. Summary consumption of energy factors for preparing and coking processes and coal derivatives department for $1 \mathrm{Mg}$ of dry coal are given in Table 3. 
Table 2. Composition of raw coke oven gas

\begin{tabular}{|l|r|r|}
\hline Component & $\mathbf{m} / \mathbf{m} \%$ & $\mathbf{v} / \mathbf{v} \%$ \\
\hline $\mathrm{H}_{2}$ & 6.0 & 41.7 \\
\hline $\mathrm{CO}$ & 4.6 & 2.3 \\
\hline $\mathrm{CH}_{4}$ & 22.6 & 19.7 \\
\hline $\mathrm{CO}_{2}$ & 3.1 & 1.0 \\
\hline $\mathrm{C}_{2} \mathrm{H}_{6}$ & 5.6 & 2.6 \\
\hline $\mathrm{H}_{2} \mathrm{~S}$ & 1.4 & 0.6 \\
\hline $\mathrm{NH}_{3}$ & 2.3 & 1.9 \\
\hline $\mathrm{H}_{2} \mathrm{O}$ & 36.2 & 28.0 \\
\hline Benzol & 4.3 & 0.8 \\
\hline Tar & 14.0 & 1.5 \\
\hline
\end{tabular}

Table 3. Usage of energy and coke oven gas for coking plant

\begin{tabular}{|l|r|r|r|}
\hline \multicolumn{1}{|c|}{ Energy carrier } & Expenditure & Income & Difference \\
\hline $\begin{array}{l}\text { Electricity } \\
{\left[\mathrm{kWh} / \mathrm{Mg}_{\mathrm{ws}}\right]}\end{array}$ & 74.07 & 39.63 & -34.44 \\
\hline Heat $\left[\mathrm{GJ} / \mathrm{Mg}_{\mathrm{ws}}\right]$ & 1.57 & 1.32 & -0.25 \\
\hline $\begin{array}{l}\text { Coke oven gas } \\
{\left[\mathrm{MJ} / \mathrm{Mg}_{\mathrm{ws}}\right]}\end{array}$ & 2687 & 6560 & +3873 \\
\hline
\end{tabular}

\subsection{Hydrogen production}

After benzol absorption step, gas stream is being subjected to the reforming technology, which comprises the following process units: coke oven gas reforming system, oxygen production installation, $\mathrm{CO}$ conversion system and the hydrolysis of COS, desulphurization system and $\mathrm{CO}_{2}$ removal system, $\mathrm{H}_{2}$ separation system and other plant. The calculations for hydrogen production were made using ChemCAD v.6.0.2 simulator for a technological process in a steady state. Calculations were made for the following assumptions:

- cleaned coke oven gas was used in reforming system at $25^{\circ} \mathrm{C}$ and saturated with water vapor and tar,

- battery heating uses $50 \%$ of the coke oven gas mixed with purified residual gas,

- separated in the Selexol system compounds of sulfur are moved to Claus installation, belonging to the technological system of coking plant

Table 4 shows the mass balance for hydrogen production process from purified coke oven gas. Table 5 shows the consumption of electricity according to installation requirements. Table 6 presents efficiency of obtaining hydrogen from purified coke oven gas, which was calculated as the ratio of chemical enthalpy of products and the enthalpy of chemical raw materials, i.e. excess gas and tar.

The separation of $\mathrm{CO}_{2}$ generated during the hydrogen production from purified coke oven gas was included. As a result carbon dioxide is being produced as a byproduct, in an amount of $3835 \mathrm{Mg} / \mathrm{h}(28555$ $\mathrm{Mg} /$ year), with a degree of purity of over $99 \%$. It can be a commercial product or a storage object. In the case of sequestration of carbon dioxide separated during hydrogen production from coke oven gas, compression, transportation and congestion in selected places of geological storage are required.
Table 4. Mass balance for hydrogen production plant

\begin{tabular}{|c|c|c|c|c|c|}
\hline \multirow[b]{2}{*}{$\begin{array}{l}\text { Stream } \\
\text { name }\end{array}$} & \multicolumn{5}{|c|}{ Expenditure/production } \\
\hline & 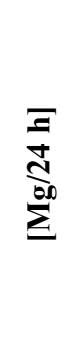 & 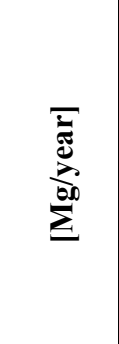 & 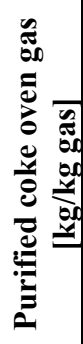 & 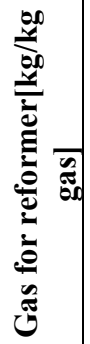 & 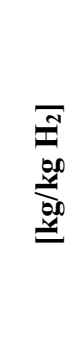 \\
\hline \multicolumn{6}{|c|}{ In (entrence) } \\
\hline $\begin{array}{l}\text { 1. Coke oven } \\
\text { gas }\end{array}$ & 47 & 14706 & 1.00 & 1.04 & 4.30 \\
\hline 2. Oxygen & 36 & 11099 & 0.75 & 0.79 & 3.24 \\
\hline 3. Tar & 15 & 4579 & 0.31 & 0.32 & 1.34 \\
\hline $\begin{array}{l}\text { 4.Water } \\
\text { supplement }\end{array}$ & 44 & 13775 & 0.94 & 0.97 & 4.03 \\
\hline 5. Steam & 40 & 12360 & 0.84 & 0,87 & 3.61 \\
\hline Summary & 182 & 56520 & 3,84 & 4,00 & 16,52 \\
\hline \multicolumn{6}{|c|}{ Out (exit) } \\
\hline 1. Hydrogen & 11 & 3425 & 0.23 & 0.24 & 1.00 \\
\hline 2. $\mathrm{CO}_{2}$ & 92 & 28555 & 1.94 & 2.02 & 8.34 \\
\hline 3. Acid gas & 2 & 663 & 0.05 & 0.05 & 0.19 \\
\hline $\begin{array}{l}\text { 4. Gas for } \\
\text { battery }\end{array}$ & 31 & 9553 & 0.65 & 0.68 & 2.79 \\
\hline 5. Waste & 45 & 13939 & 0.95 & 0.99 & 4.07 \\
\hline $\begin{array}{l}\text { 6. Steam } \\
\text { production }\end{array}$ & 1 & 387 & 0.03 & 0.03 & 0.11 \\
\hline Summary & 182 & 56523 & 3.84 & 4.00 & 16.52 \\
\hline
\end{tabular}

Assumptions concerning the conditions for the transport of carbon dioxide and its injection in geological deposits are:

- carbon dioxide will be transported in the liquid phase,

- the pressure at the inlet to a transport system (pipe) is 120 bar, which allows to transport of $\mathrm{CO}_{2}$ at about 100 $150 \mathrm{~km}$ distance and the congestion it in geological structures without additional compression.

The values of electric energy requirements for $\mathrm{CO}_{2}$ compression system for transport and storage, and corresponding carbon dioxide emissions are shown in Table 7. Table 8 shows the CF associated with net production of electricity and heat for hydrogen production from purified coke oven gas.

Based on the collected data (Tables 3-5) from process simulator (ChemCAD) production indicators and consumption of electricity and heat throughout the life cycle of the technology of hydrogen production from purified coke oven gas at all process stages were calculated. The values of these indicators are referenced to the unit mass of coking coal and the unit mass of produced hydrogen. 
Table 5. Electric energy usage for hydrogen production plant

\begin{tabular}{|c|c|c|c|c|}
\hline \multirow[b]{2}{*}{ Department } & \multirow[b]{2}{*}{ 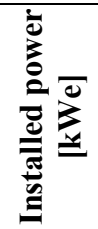 } & \multicolumn{3}{|c|}{ Expediture of energy } \\
\hline & & 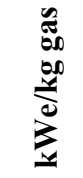 & 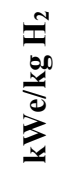 & $\sum_{0}^{5}$ \\
\hline 1. Oxygen & 564 & 0.29 & 1.23 & 4.20 \\
\hline $\begin{array}{l}\text { 2. Gas reformer } \\
\text { (power pumps) }\end{array}$ & 17 & 0.01 & 0.04 & 0.10 \\
\hline 3. Gas pressing & 147 & 0.08 & 0.32 & 1.10 \\
\hline $\begin{array}{l}4 . \\
\text { Desulphurization }\end{array}$ & - & 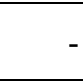 & - & \\
\hline $\begin{array}{l}\text { 5. Gas cooling } \\
\text { system }\end{array}$ & 12 & 0.01 & 0.03 & 0.1 \\
\hline $\begin{array}{l}\text { 6. Gas } \\
\text { compresion }\end{array}$ & 1177 & 0.62 & 2.56 & 8.80 \\
\hline $\begin{array}{l}\text { 7. Removal of } \\
\text { acid gas - Selexol }\end{array}$ & 213 & 0.11 & 0.46 & 1.60 \\
\hline $\begin{array}{l}\text { 8. Claus/Scot- } \\
\text { installation }\end{array}$ & & & & \\
\hline Summary & 2130 & 1.12 & 4.64 & 15.9 \\
\hline
\end{tabular}

Table 6. Process efficiency

\begin{tabular}{|l|r|}
\hline Process efficiency & Wd \\
\hline Gas after reformer & $90.24 \%$ \\
\hline Gas PSA & $85.02 \%$ \\
\hline Hydrogen & $71.28 \%$ \\
\hline
\end{tabular}

Table 7. Electric energy requirement for the $\mathrm{CO}_{2}$ compression step and related emissions.

\begin{tabular}{|l|r|}
\hline Parameter & \multicolumn{1}{|l|}{ Value } \\
\hline $\begin{array}{l}\mathrm{CO}_{2} \text { stream for } \\
\text { sequestration, } \mathrm{Mg} \text { per year }\end{array}$ & 28559 \\
\hline $\begin{array}{l}\mathrm{CO}_{2} \text { stream for } \\
\text { sequestration, } \mathrm{kg} \mathrm{CO} / \mathrm{Mg}_{\text {coal }}\end{array}$ & 227.24 \\
\hline $\begin{array}{l}\mathrm{CO}_{2} \text { stream for } \\
\text { sequestration, } \mathrm{kg} \mathrm{CO} / \mathrm{Mg} \\
\mathrm{H}_{2}\end{array}$ & 8346.03 \\
\hline $\begin{array}{l}\text { Compression electricity } \\
\text { power, MWe }\end{array}$ & 0.32 \\
\hline $\begin{array}{l}\text { Energy consumption for } \\
\text { compressing, } \mathrm{kWh} / \mathrm{Mg} \text { coal }\end{array}$ & 19.13 \\
\hline $\begin{array}{l}\text { Energy consumption for } \\
\text { compressing, } \mathrm{kWh} / \mathrm{Mg} \mathrm{H}_{2}\end{array}$ & 702.71 \\
\hline $\begin{array}{l}\mathbf{C O} \text { emission indicator, kg } \\
\mathbf{C O}_{2} / \mathbf{M g}_{\text {coal }}\end{array}$ & $\mathbf{1 7 . 4 6}$ \\
\hline $\begin{array}{l}\mathbf{C O} \text { emission indicator, kg } \\
\mathbf{C O}_{2} / \mathbf{M g} \mathbf{H}_{2}\end{array}$ & $\mathbf{6 4 1 . 1 6}$ \\
\hline
\end{tabular}

Based on the above-mentioned indicators, CF associated with the consumption of heat and electricity in the coking process and coke oven gas reforming in the hydrogen production were calculated. Coke oven gas is only one of the products of the coking process therefore, to the individual coking products used to produce hydrogen, carbon dioxide emissions in proportion to their contribution to the total amount of energy in all products of coking has been attributed.
Based on the above-mentioned information about distribution of energy in the coking products and basic balance data of the major process streams (ChemCAD), share of $\mathrm{CO}_{2}$ emission from the coking process connected to raw materials supplied to reformer have a value of 0.1465 for hydrogen production from purified coke oven gas.

Table 8. CF related to the production of net electricity and heat for the hydrogen production from purified coke oven gas.

\begin{tabular}{|c|c|c|}
\hline \multirow[t]{3}{*}{$\mathrm{H}_{2}$ production } & \multirow{2}{*}{\multicolumn{2}{|c|}{$\begin{array}{c}\mathrm{CO}_{2} \text { emission indicators } \\
\text { related with net production of } \\
\text { electricity } \\
\text { Electricity } \\
\end{array}$}} \\
\hline & & \\
\hline & $\mathrm{kg} \mathrm{CO} / \mathrm{Mg}$ coal & $\begin{array}{c}\mathrm{kg} \mathrm{CO} \\
\mathrm{H} 2 \\
\mathrm{H} 2\end{array}$ \\
\hline $\begin{array}{l}\text { From purified } \\
\text { coke oven gas. }\end{array}$ & 119.36 & 4383.84 \\
\hline \multirow[t]{3}{*}{$\begin{array}{l}\text { Including: } \\
\text { Coking process, } \\
\mathrm{H}_{2} \text { production } \\
\end{array}$} & $\begin{array}{r}4.23 \\
115.13\end{array}$ & $\begin{array}{r}155.19 \\
4228.66\end{array}$ \\
\hline & \multicolumn{2}{|c|}{ Heat } \\
\hline & $\mathrm{kg} \mathrm{CO} / \mathrm{Mg}$ coal & $\begin{array}{c}\mathrm{kg} \mathrm{CO} \mathrm{CO}_{2} / \mathrm{Mg} \\
\mathrm{H}_{2} \\
\end{array}$ \\
\hline $\begin{array}{l}\text { From purified } \\
\text { coke oven gas }\end{array}$ & 14.00 & 513.79 \\
\hline \multirow[t]{3}{*}{$\begin{array}{l}\text { Including: } \\
\text { Coking process, } \\
\mathrm{H}_{2} \text { production } \\
\end{array}$} & $\begin{array}{l}4.10 \\
9.91\end{array}$ & $\begin{array}{l}149.72 \\
364.10\end{array}$ \\
\hline & \multicolumn{2}{|c|}{ Summary } \\
\hline & $\mathrm{kg} \mathrm{CO}_{2} / \mathrm{Mg}_{\text {coal }}$ & $\begin{array}{c}\mathrm{kg} \mathrm{CO} \mathrm{CO}_{2} / \mathrm{Mg} \\
\mathrm{H}_{2} \\
\end{array}$ \\
\hline $\begin{array}{l}\text { From purified } \\
\text { coke oven gas. }\end{array}$ & 133.35 & 4897.63 \\
\hline $\begin{array}{l}\text { Including: } \\
\text { Coking process, } \\
\mathrm{H}_{2} \text { production } \\
\end{array}$ & $\begin{array}{r}8.30 \\
125.04\end{array}$ & $\begin{array}{r}304.91 \\
4592.72\end{array}$ \\
\hline
\end{tabular}

\section{Conclusions}

Hydrogen production technology from purified coke oven gas was subjected by $\mathrm{CF}$ analysis.

According to the LCA methodology including: coal mining, transport of coal to coking plants by railway, coking process with auxiliary operations, obtaining hydrogen from purified coke oven gas and sequestration of captured $\mathrm{CO}_{2}$.

Hydrogen yield for considered technology was: $0.1859 \mathrm{Mg} \mathrm{H}_{2}$ per $1 \mathrm{Mg}$ of coal and $0.0076 \mathrm{Mg} \mathrm{H}_{2}$ per $1 \mathrm{GJ}$ net calorific value contained in coal. Conversion efficiency of chemical enthalpy is equal to $71.3 \%$.

Carbon Footprint counted for $1 \mathrm{Mg}$ of dry coal was $1106.3 \mathrm{~kg} \quad \mathrm{CO}_{2}$ and consists of emissions from the production of raw materials $(14.0 \mathrm{~kg}$ $\left.\mathrm{CO}_{2} / \mathrm{Mg}_{\text {coal }}\right)$, transport of coal $\left(1.1 \mathrm{kgCO}_{2} / \mathrm{Mg}_{\text {coal }}\right)$, net energy consumption (938.9 $\mathrm{kg} \mathrm{CO}_{2} / \mathrm{Mg}_{\text {coal }}$ ), $\mathrm{CO}_{2}$ indirect emission $\quad\left(22.5 \quad \mathrm{~kg} \quad \mathrm{CO}_{2} / \mathrm{Mg}_{\text {coal }}\right), \quad \mathrm{CO}_{2}$ captured for sequestration (1689.8 $\mathrm{kg} \quad \mathrm{CO}_{2} / \mathrm{Mg}_{\text {coal }}$ ) and energy consumption for sequestration (129.8 $\left.\mathrm{kg} \mathrm{CO}_{2} / \mathrm{Mg}_{\text {coal }}\right)$. 
CF counted in reference to $1 \mathrm{GJ}$ of chemical entalphy contained in raw coal is $41.6 \mathrm{~kg} \mathrm{CO} / \mathrm{GJ}$, it consists of emissions from the production of raw materials $(0,5 \mathrm{~kg}$ $\left.\mathrm{CO}_{2} / \mathrm{GJ}\right)$, coal transportation $(0.0 \mathrm{~kg} \mathrm{CO} / \mathrm{GJ})$, net energy consumption $(35.3 \mathrm{~kg} \mathrm{CO} / \mathrm{GJ}), \mathrm{CO}_{2}$ indirect $\left.\begin{array}{lllllll}\text { emission } & (0.8 & \mathrm{kg} & \mathrm{CO}_{2} / & \mathrm{GJ}\end{array}\right), \mathrm{CO}_{2}$ captured for sequestration ( $63.5 \mathrm{~kg} \quad \mathrm{CO}_{2} / \mathrm{GJ}$ ) and energy consumption for sequestration $\left(4.9 \mathrm{~kg} \mathrm{CO}_{2} / \mathrm{GJ}\right)$.

Value of $\mathrm{CF}$ in reference to $1 \mathrm{Mg}$ of produced hydrogen was $5463.7 \quad \mathrm{~kg} \quad \mathrm{CO}_{2}$. This contributes to the emissions resulting from the production of raw materials (69.3 $\mathrm{kg} \mathrm{CO} / \mathrm{Mg} \mathrm{\textrm {H } _ { 2 }}$ ), coal transportation (5.7 $\mathrm{kg} \mathrm{CO}_{2} / \mathrm{Mg} \mathrm{H}_{2}$ ), net energy consumption (4637.4 kg $\mathrm{CO}_{2} / \mathrm{Mg} \mathrm{H}$ ), $\mathrm{CO}_{2}$ indirect emission $\left(110.2 \mathrm{~kg} \mathrm{CO}_{2} / \mathrm{Mg}\right.$ $\mathrm{H}_{2}$ ), $\mathrm{CO}_{2}$ captured for sequestration ( $8346.0 \mathrm{~kg} \mathrm{CO} / \mathrm{Mg}$ $\mathrm{H}_{2}$ ) and energy consumption for sequestration $(641.2 \mathrm{~kg}$ $\mathrm{CO}_{2} / \mathrm{Mg} \mathrm{H}_{2}$ ).

\section{Acknowledgments}

Financial support for this study was provided by the AGH University of Science and Technology (framework no. 11.11.210.244)

\section{References}

1. Massachusetts Institute of Technology, MIT 2007: The Future of Coal

2. H.H. Schobert, C. Song, Fuel 81, 16 (2002)

3. Coal industry across Europe 2008 (Eurocoal, Bruksela, 2008)

4. Survey of Energy Resources. Interim Update (World Energy Council, Londyn, 2009)

5. www.crugroup.com

6. J. Mielnikiewicz, M. Ściążko, R. Cieślar, Karbo Wydanie Specjalne, 4-12 (2007)

7. Coke Market Report, Analysis of the Global Coke \& Coking Coal Markets (Resource-Net, Brussels, Belgium, 2007)

8. Coke Market Survey (Resource-Net, Brussels, Belgium, 2007)

9. J. L. Wang, X. C. Quan, L. B. Wu, Y. Qian, W. Hegemann, Process Biochemistry 38, 777-781 (2002)

10. E.E. Chang, H.J. Hsing, P.C. Chiang, M.Y. Chen, J.Y. Shyng, Journal of Hazardous Materials 156 , 560-567(2008)

11. W.H. Zhang, C.H. Wei, C.H. Feng, B. Yan, N. Li, P.A. Peng, J.M. Fu, Science of the Total Environment 432, 396-403 (2012)

12. A.Karcz, A. Sobolewski, 2009, Karbo 2, 112-120 (2009)

13. Q. Sun , J. Dong, X. Guo, A. Liu, J. Zhang, Ind. Eng. Chem. Res. 51 (17), 6205-6211 (2012)

14. G. Stiegel, M. Ramezan, International Journal of Coal Geology 65, 173- 190 (2006)

15. J.A. Turner, Science 305, 972-974 (2004)

16. B. Behera, R. Balasundaram, K. Gadgil, D. Sharma, Energy Sources Part A 29, 761-7 (2007)

17. K.L. Kovács, G. Maroti, G. Rákhely, International Journal of Hydrogen Energy 31, 1460-8 (2006)
18. T.A. Moore, S. Pearce, International Journal of Coal Geology 65, 171-172 (2006)

19. IEA Energy Technology Essentials, Hydrogen Production \& Distribution, Apr. 05 (2007)

20. T. Wiltowski, K. Mondal, A. Campen, D. Dasgupta, A. Konieczny, Int. J. Hydrogen Energy 33, 293 (2008)

21. A. J. Minchener, Fuel 84, 2222-2233 (2005)

22. Y. Wu, J. Wang, S. Wu, S. Huang, J. Gao, Fuel Processing Technology 92, 523-530 (2011)

23. T. Take, K. Tsurutani, M. Umeda, Journal of Power Sources 164, 9-16 (2007)

24. L. Shen, Y. Gao, J. Xiao, BIOMASS AND BIOENERGY 32, 120-127 (2008)

25. M. Wackernagel, W.E. Rees, New Society, (Gabriola Island, British Columbia, 1996)

26. A.Y. Hoekstra, P.Q. Hung, Value of Water Research Report Series 11 (UNESCO-IHE Institute for Water Educa-tion, 2002)

27. A.M. Leach, J.N. Galloway, A. Bleeker, J.W. Erisman, R. Kohn, J. Kitzes, Environ. Dev. 1, 40-66 (2012)

28. T. Wiedmann, J. Minx, Nova Science Publishers 1, 1-11 ( Hauppauge, NY,USA, 2008)

29. J. Kitzes, M. Wackernagel, Ecological indicators 9, 812-817 (2009)

30. D. Yajie, X. Beicheng, C. Weidong, Environmental Science \& Policy Volume 44, 181-189 (2014)

31. A. Galli, T. Wiedmannb, E. Ercinc, D. Knoblauchd, B. Ewinge, S. Giljumf, Ecological Indicators 16, 100-112 (2012)

32. G.R. Cranstona, G.P. Hammonda, Ecological Indicators 16, 91-99 (2012)

33. K. Fang, R. Heijungs, G. R. de Snoo, Ecological Indicators 36, 508- 518 (2014)

34. D. Burchart-Korol, K. Czaplicka-Kolarz, A. Fugiel, A. Rejman-Burzyńska, Przemysł Chemiczny 94 (9), 1584-1589 (2015)

35. K. Czaplicka-Kolarz, A. Fugiel, D. Burchart-Korol, Polityka Energetyczna 17 (4), 263-275 (2014)

36. P. Krawczyk, J. Krzemień, D. Burchart-Korol, K. Czaplicka-Kolarz, Przemysł Chemiczny 93 (12) , 2232-2236 (2014)

37. PN-EN ISO 14040:2009

38. ISO/TS 14067:2014 